\title{
MENINGKATKAN KETERAMPILAN MOTORIK HALUS ANAK MELALUI BERMAIN DENGAN BARANG BEKAS
}

\author{
Sabaria Agustina \\ fauzitina@yahoo.co.id \\ M. Nasirun \\ h.m.nasirun@gmail.com \\ Delrefi D \\ an.refi@gmail.com
}

\begin{abstract}
The problem in this research is the low of fine motor skills of child. This classroom action research aims to improve the fine motor of children through playing activities with the media used plastic bottles and cartons of former group B PAUD Aulia Bengkulu City. Whether through the activities of playing with used media used plastic bottles and used cardboard can improve the 3 aspects of tightening, holding, and coordinating the eyes and hands. Subjects in this study were the children of group $B$ who held 10 children consisting of 6 girls, and 4 boys. This classroom action research is conducted in 2 cycles and each cycle consists of three meetings. Technique is observation, with data analysis technique use average. The result of this study is proven by the fine motor skills of children can be improved through playing activity with the media used plastic bottles and used cardboard, with learning mastery of $88 \%$ average total motor fine result of children 4.4 (good). From the results of the research that produces, it is advisable for teachers to apply play activities with the media used plastic bottles and used cardboard, and for further research is expected to research about fine motor skills through play activities with other aspects.
\end{abstract}

Keywords: Fine Motor; Playing Activities; Media Goods

\section{PENDAHULUAN}

PAUD adalah pendidikan yang cukup penting dan bahkan menjadi landasan kuat untuk mewujudkan generasi yang cerdas. PAUD merupakan salah satu bentuk penyelenggaraan pendidikan yang menitikberatkan pada peletakan dasar kearah pertumbuhan dan perkembangan fisik (koordinasi motorik halus dan kasar), kecerdasan (daya pikir, daya cipta, kecerdasan emosi, kecerdasan spiritual), sosio emosional (sikap dan prilaku serta agama) bahasa dan komunikasi, sesuai dengan keunikan dan tahap-tahap perkembangan yang dilalui oleh anak usia dini yang menanamkan nilai-nilai luhur kemanusiaan (pengembangan intelegensi, karakter, kreativitas, moral dan kasih sayang) sangatlah perlu diberikan pada anak-anak sejak usia dini.

Anak usia dini adalah sosok individu yang sedang menjalani suatu proses perkembangan dengan pesat dan fundamental bagi kehidupan selanjutnya. Anak usia dini berada pada rentang usia 0-8 tahun. Usia ini merupakan usia anak mengalami pertumbuhan dan perkembangan yang pesat. Usia dini disebut sebagai usia emas (Sujiono, 2009: 6). Di dalam UU No. 20 Tahun 2003 tentang Sistem Pendidikan Nasional Bab 1 Pasal 1 Ayat 14 menyatakan bahwa PAUD adalah 
suatu upaya pembinaan yang ditujukan kepada anak sejak lahir sampai dengan usia enam tahun yang dilakukan melalui pemberian rangsangan pendidikan untuk membantu pertumbuhan dan perkembangan jasmani dan rohani agar anak memiliki kesiapan dalam memasuki pendidikan lebih lanjut.

Menurut Permendikbud No 137 Tahun 2014 Tentang Standar nasional Pendidikan Anak Usia Dini pasal 10 ayat 1 tentang lingkup perkembangan sesuai tingkat usia anak meliputi aspek nilai agama dan moral, fisik-motorik, kognitif, bahasa, sosial emosional, dan seni. Aspek-aspek perkembangan tersebut dipadukan dalam bidang pengembangan pembentukan perilaku melalui pembiasaan yang terdiri dari: moral dan nilai-nilai agama, sosial emosional, dan kemandirian, dan pengembangan kemampuan dasar, yang terdiri dari: bahasa, fisik/motorik, seni dan kognitif.

Masa usia dini adalah masa yang sangat menentukan bagi perkembangan dan pertumbuhan anak selanjutnya karena merupakan masa peka dan masa dalam kehidupan anak. Pada anak usia Taman Kanak-kanak (TK) aspek perkembangan anak akan sangat jelas terlihat pula. Salah satu kemampuan anak yang berkembang dengan pesat adalah kemampuan fisik atau motorik. Seperti yang dikemukakan oleh Aisyah, dkk (2008;4.42) bahwa motorik merupakan keterampilan pengendalian gerakan tubuh melalui kegiatan yang terkoordinir antara susunan saraf, otot, dan otak. Keterampilan motorik meliputi motorik kasar dan halus. Keterampilan ini akan berpengaruh pada kemampuan social emosional, bahasa, dan fisik anak.

Motorik halus adalah yang menggunakan otot-otot halus atau sebagian anggota tubuh tertentu (tangan dan jari-jari) dan dipergunakan untuk memanipulasi lingkungan. Sebagaimana diketahui bahwa control tangan dimulai dari bahu yang menghasilkan gerak lengan yang kasar, menjadi gerak siku yang baik dan akhirnya gerakan pergelangan tangan dan jari-jari (Sunardi, 2007: 114).

Keterampilan motorik halus yaitu gerakan terbatas dari bagian-bagian meliputi otot kecil, terutama dibagian jarijari tangan, contohnya adalah menulis, menggunting, menggambar, dan memegang sesuatu dengan ibu jari dan telunjuk (Hildayani, dkk 2007: 8,9). Keterampilan motorik halus anak sangatlah penting ditingkatkan karena secara tidak langsung perkembangan motorik halus anak akan menentukan keterampilan dalam bergerak misalnya menulis dan menggunting Pergerakan tersebut melibatkan bagian-bagian tubuh tertentu dan diawali oleh perkembangan otot-otot kecil seperti keterampilan menggunakan jari-jemari tangan dan pergelangan tangan yang luwes, melatih koordinasi mata.

Pendidikan di Taman Kanak-kanak dilaksanakan dengan prinsip "Bermain sambil belajar, atau belajar sambil bermain". Seorang pendidik diharapkan memiliki pemikiran yang kreatif dan inovatif agar anak bisa merasakan senang, tenang, aman, dan nyaman selama dalam proses belajar mengajar, sehingga dapat mencapai sesuai dengan perkembangan anak. Dalam standar kompetensi kurikulum Taman Kanak-kanak tercantum bahwa tujuan pendidikan di Taman Kanak-kanak adalah membantu mengembangkan berbagai potensi anak baik fisik maupun psikis yang meliputi moral dan nilai-nilai agama, social emosional, kognitif, bahasa, fisik motorik, kemandirian dan seni untuk memsuki pendidikan selanjutnya.

Keterampilan motorik halus anak ada empat macam yaitu, menjimpit, memegang, konsentrasi, dan koordinasi mata dan tangan (Yamin,2013:101). Dapat dikatakan bahwa kegiatan bermain yang akan peneliti laksanakan dapat membantu dalam meningkatkan keterampilan motorik 
halus anak yaitu dengan motede bermain dengan mengunakan barang bekas (botol plastik dan kardus bekas).

Berdasarkan observasi peneliti di Paud Aulia Kota Bengkulu kegiatan perkembangan dalam keterampilan motorik halus anak masih kurang, dilihat dari semua kegiatan yang diterapkan dikelas oleh guru selama ini hanya kegiatan yang membuat anak bosan dalam mengikuti proses belajar dan tidak banyak kegiatan yang dapat meningkatkan keterampilan motorik halus anak. Kegiatan yang kurang dalam menstimulasi keterampilan motorik halus anak dapat menimbulkan gerak tangan anak akan kaku sehingga keterampilan motorik halus anak belum meningkat sesuai dengan aspeknya.

Oleh karena itu peneliti mendapatkan kebanyakan anak dikelompok B masih banyak yang belum dapat memegang pensil dan gunting dengan benar sehingga ketika anak diminta menulis, kebanyakan anakanak belum bisa menulis dengan benar. Terkait dengan hal tersebut peneliti ingin memberikan penerapkan kegiatan yang dapat membantu anak dalam meningkatkan keterampilan motorik halus dengan kegiatan bermain dengan media barang bekas yang dapat anak temui dilingkungannya sendiri.

Peneliti memilih menggunakan Penelitian Tindakan Kelas (PTK) dengan judul "Meningkatkan Keterampilan Motorik Halus Melalui Kegiatan Bermain Dengan Media Barang Bekas Botol Plastik Dan Kardus Bekas"

\section{Identifikasi Masalah}

Berdasarkan uraian latar belakang masalah diatas dapat diidentifikasikan beberapa permasalahan sebagai berikut : Fokus penelitian ini adalah keterampilan motorik halus. Keterampilan motorik halus anak belum berkembang optimal sehingga anak masih terlihat kaku dalam melakukan kegiatan motorik halus. Untuk memudahkan peneliti mengidentifikasi tentang keterampilan motorik halus yang meliputi menjimpit, memegang, dan koordinasi mata dan tangan. Masalah yang ada dilapangan yaitu kemampuan anak dalam menjimpit, memegang, dan koordinasi mata dan tangan, yang masih kurang.

Fokus penelitian kedua adalah kegiatan bermain dengan media barang bekas. Bermain adalah kegiatan yang dilakukan demi kesenangan tanpa mempertimbangkan hasil akhir dan dilakukan secara suka rela, tanpa paksaan atau tekanan dari pihak luar. Sedangkan barang bekas merupakan media pebelajaran yang dianggap tidak bernilai tetapi dapat ditemukan dilingkungan anak.

Menurut kamus besar bahasa Indonesia 2003 keterampilan berasal dari kata "terampil" yang artinya cakap dalam menyelesaikan tugas, mampu dan cekatan. Kata keterampilan sama artinya dengan cekatan. Keterampilan atau cekatan menurut Iverson (2001) menyatakan bahwa keterampilan membutuhkan pelatihan dan kemampuan dasar yang dimiliki setiap orang dapat lebih membantu menghasilkan sesuatu yang lebih bernilai dengan lebih cepat.

Keterampilan motorik merupakan kesempatan yang luas untuk bergerak, pengalaman belajar untuk menemukan aktivitas sensori motor yang meliputi penggunaan otot-otot besar dan kecil memungkinkan anak untuk memenuhi perkembangan perceptual motorik menurut Yuliani (2011: 63). Kemendiknas (2010:15) motorik halus adalah gerakan yang melibatkan bagian-bagian tubuh tertentu yang dilakukan oleh otot-otot kecil. Oleh karena itu motorik halus tidak terlalu membutuhkan tenaga, tetapi membutuhkan koordinasi yang cermat secara ketelitian.

Menurut Ningsih (2015: 3) tujuan keterampilan motorik halus diantaranya adalah : 
a) Meningkatkan keterampilan motorik halus anak dapat mengembangkan keterampilan motorik halus anak khususnya koordinasi antara mata dan tangan anak secara optimal.

b) Saat anak mengembangkan keterampilan motorik halusnya diharapkan anak dapat menyesuaikan lingkungan social dengan baik serta menyediakan kesempatan untuk mempelajari keterampilan sosialnya karena setiap pengembangan tidak dapat terpisah satu sama lain.

c) Semakin banyak anak melakukan sendiri suatu kegiatan maka semakin besar juga rasa percaya dirinya.

Menurut Fadillah (2012:211-212) berpendapat bahwa macam-macam media pembelajaran untuk anak usia dini dapat digolongkan menjadi empat, yaitu:

1. Media Visual, Media visual adalah media yang menyampaikan pesan melalui penglihatan pemirsa atau media yang hanya dapat dilihat. Jenis media visual ini tampaknya yang sering digunakan oleh guru untuk membantu menyampaikan isi dari tema pembelajaran yang sedang dipelajari. Media visiual terdiri atas media yang dapat diproyeksikan (projected visual) media yang tidak dapat diproyeksikan (non-projected visual).

2. Media audio adalah media yang mengandung pesan dalam bentuk auditif (hanya dapat didegar) yang dapat merangsang pikiran, perasaan, perhatian, dan kemauan anak untuk mempelajari isi tema. Contoh media audio adalah program kaset suara dan program radio. Penggunaan media audio dalam kegiatan pembelajaran di PAUD pada umumnya untuk melatih keterampilan yang berhubungan dengan aspek-aspek keterampilan mendengarkan, dan sifatnya yang auditif, media ini mengandung kelemahan yang harus di atasi dengan cara memanfaatkan media lainnya.

3. Media Audiovisual, Media audiovisual merupakan kombinasi dari media audio dan media visual atau biasa disebut media pandang-dengar. Dengan menggunakan media audiovisual ini maka penyajian isi tema kepada anak akan semakin lengkapdan optimal. Selain itu, media ini dalam batas-batas tertentu dapat menggantikan peran dan tugas guru.

4. Media Taktil, Taktil berasal dari kata Tactile yang artinya sentuhan atau raba, segala sesuatu yang berkaitan dengan indera peraba yaitu tangan dan kaki. Gaya belajar taktil mengakomodasi gerak motorik halus anak. Pembelajaran bergaya taktil bisa mengingat hal baik jika mereka menggunakan kemampuan motorik halusnya untuk membuat atau mengendalikan bahan pelajaran yang baru sedang dipelajari atau pekerjaan yang sulit.

Berdasarkan uraian macam-macam media pembelajaran diatas maka penulis menyimpulkan bahwa media pembelajaran yang cocok dalam proses penelitian ini adalah media pembelajaran media taktil, kerena dengan menggunakan media taktil anak dapat menggunakan gerakan ditangan seperti meraba, memegang dan sebagainya sehingga keterampilan motorik halus anak dapat meningkat sesuai dengan harapan peneliti.

Arti barang bekas menurut kamus besar bahasa Indonesia yaitu suatu barang yang tidak dapat dipergunakan lagi baik sisa-sisa dari rumah tangga maupun sisasisa dari pabrik. Bahan bekas yang biasanya disebut sebagai sampah ini dapat berupa plastik, kaleng, kertas, dan kardus. Benda tersebut dapat dimanfaatkan menjadi sebuah benda yang memiliki nilai tinggi. Keberadaan barang bekas yang tidak 
terpakai sangat mudah ditemukan di lingkungan sekitar (Nilawati, 2010:3)

\section{Jenis-jenis barang bekas :}

1. Koran, Ternyata koran bekas di rumah Anda pun dapat dimanfaatkan sebagai penyedot emas, penemuan dari para ilmuwan Jepang ini merupakan satu terobosan yang cukup menggembirakan. Koran bekas merupakan salah satu bahan ramuan gel yang ramah lingkungan yang dapat diolah untuk memisahkan emas dari sampah elektronik.

2. Botol Plastik, Sampah botol plastik dari bekas kemasan minuman yang seringkali dianggap hanyalah sampah plastik tak berharga dan menjadi penghuni tempat sampah, ternyata bisa disulap jadi aneka bentuk benda bermanfaat.

3. Kardus, Karton field atau kardus merupakan bahan limbahan yang dapat digunakan ditengan masyarakat untuk mengepak atau mengemas barang

4. Pipet, Pipet dapat dimanfaatkan sebagai bahan pembuatan hiasan rumah seperti taplak meja, tirai,dan pembuatan bunga dari pipet.dll.

Dalam penelitian ini botol plastik dan kardus dimanfaatkan sebagai alat bermain anak kelompok B PAUD Aulia Kota Bengkulu untuk kegiatan bermain. Pada saat kegiatan bermain anak-anak akan menggunakan barang bekas tersebut untuk membuat, pesawat,kupu-kupu,lebah,kura-kura, dan ikan

\section{METODE}

Penelitian ini dilaksanakan untuk melakukan tindakan kelas dalam rangka untuk perbaikan pembelajaran dalam kegiatan kegiatan untuk meningkatkan keterampilan motorik halus pada anak kelompok B PAUD Aulia Kota Bengkulu. Metode yang digunakan adalah penelitian tindakan kelas (PTK). Menurut Suharsimi
Arikunto, urutan tindakan dalam setiap siklusnya terdiri atas empat tahapan yaitu Perencanaan, Pelaksanaan, Pengamatan, dan Refleksi.

Tahap-tahap penelitian terjadi secara berulang-ulang sampai mencapai keberhasilan penelitian. Tujuan utama penelitian tindakan kelas ini untuk memecahkan masalah keterampilan motorik halus yang nyata yang terjadi di kelompok B PAUD Aulia melalui bermain menggunakan media barang bekas.

Pada penelitian tindakan kelas, perbaikan-perbaikan dilakukan secara bertahap dan terus menerus selama penelitian dilakukan sehingga didapatkan hasil terbaik sesuai yang diinginkan. Pada penelitian ini penulis menggunakan model PTK, Menurut Arikunto $(2009 ; 16)$, secara garis besar terdapat empat tahapan yang lazim ditemui, yaitu (1) Perencanaan, (2) Pelaksanaan, (3) Pengamatan, (4) Refleksi.

Adapun tahap-tahap yang akan dilakukan pada siklus I adalah :

\section{Perencanaan (Planning)}

Perencanaan pembuatan mencangkup semua langkah tindakan dimulai dari Rencana Pelaksanaan Pembelajaran Harian (RPPH) dan Rencana Pelaksanaan Pembelajaran Mingguan (RPPM), dan langsung menentukan tema dan subtema yang sesuai untuk diajarkan, menyediakan media atau alat peraga untuk pengajaran. Menentukan metode atau teknik bermain, mengalokasikan waktu, serta menyediakan instrumen observasi dan evaluasi.

\section{Pelaksanaan/ Tindakan (Action)}

Tahap ini merupakan implementasi dari semua rencana yang dibuat kemudian semua perencana itu dilaksanakan dalam kegiatan pembelajaran. Kegiatan yang dilaksanakan didalam kelas adalah pelaksanaan di teori pendidikan dan teknik mengajar yang sudah disiapkan 
sebelumnya dan hasilnya diharapkan meningkat efektivitas.

\section{Pengamatan / Observasi}

Tahap pengamatan atau observasi yang efektif berdasarkan pada lima dasar yaitu: a) harus ada perencanaan bersama antara guru dan pengamat. b) fokus observasi harus diterapkan bersama. c) guru dan pengamat harus membangun kreteria observasi bersama-sama. d) pengamat harus memiliki keterampilan mengobservasi. e) observasi akan bermanfaat jika balikan diberikan segera dan mengikuti berbagai aturan (Aqib, dkk. 2009;10)

Pengumpulan data observasi dilakukan sendiri oleh peneliti dan dibantu dengan teman sejawat di kelas B agar dapat memaksimalkan penelitian ini.

\section{Refleksi}

Tahap ini adalah tahap memproses data yang didapat pada saat melakukan pengamatan atau observasi, kemudian ditafsirkan dan dianalisis. Hasil analisis ini digunakan sebagai bahan refleksi apakah diperlukan tindak lanjutannya. Proses refleksi ini memegang peran yang penting dalam menemukan suatu keberhasilan PTK apabila hasil yang dicapai belum mencapai cerita keberhasilan maka akan dilakukan siklus berikutnya. Dengan tahapan-tahapan kegiatan sebagaimana siklus pertama.

Pelaksanaan setiap siklus dilakukan untuk mengetahui peningkatan dari keterampilan motorik halus anak. Kegiatan refleksi dilakukan berdasarkan analisa terhadap data yang telah didapat selama pembelajaran dan observasi, kemudia direfleksikan untuk melihat kekurangankekurangan yang ada, mengkaji apa yang telah dan belum terjadi, mengapa terjadi demikian, dan langkah apa saja yang perlu dilakukan untuk perbaikan. Hasil refleksi ini digunakan untuk menetapkan langkah selanjutnya, apakah berhenti atau membuat rencana tindakan pada siklus II.

Indikator keberhasilan dalam penelitian ini adalah meningkatkan keterampilan motorik halus anak yang dapat dilihat selama proses pembelajaran berlangsung, maupun dari peningkatan persentase hasil kemampuan anak. Keberhasilan penelitian tindakan kelas ini ditandai dengan adanya perbaikan.

Adapun keberhasilan akan terlihat apabila keterampilan motorik halus melaui metode bermain dengan media barang bekas mengalami peningkatan. kriteria keberhasilan dari penelitian ini adalah apabila $75 \%$ dari jumlah anak mendapat kriteria baik

\section{HASIL DAN PEMBAHASAN}

Tabel 1. Hasil Perbandingan Pengamatan Peningkatan Keterampilan Motorik Halus Anak Antara Siklus I Dan Siklus II

\begin{tabular}{cccc}
\hline Nama anak & Siklus I & Siklus II & Ket \\
\cline { 2 - 4 } & $\begin{array}{c}\text { Pertemuan } \\
\text { III }\end{array}$ & $\begin{array}{c}\text { Pertemu } \\
\text { an III }\end{array}$ & \\
\hline Rash & 3 & 4 & Meningkat \\
\hline Nf & 3.16 & 4.33 & Meningkat \\
\hline Vt & 3.33 & 4.5 & Meningkat \\
\hline Zz & 3 & 4.83 & Meningkat \\
\hline Rf & 3 & 4 & Meningkat \\
\hline Aq & 3.16 & 4.16 & Meningkat \\
\hline Sc & 3.5 & 4.83 & Meningkat \\
\hline Lia & 3 & 4.33 & Meningkat \\
\hline Aty & 3.5 & 4.83 & Meningkat \\
\hline Farz & 2.66 & 4.16 & Meningkat \\
\hline Rata-rata & 31.3 & 4,4 & Meningkat \\
\hline $\begin{array}{c}\text { Ketuntasan } \\
\text { klasikal }\end{array}$ & $62,6 \%$ & $88 \%$ & Meningkat \\
\hline & & & \\
\hline
\end{tabular}

Berdasarkan tabel hasil perbandingan pengamatan peningkatan keterampilan motorik halus anak antara siklus I dan siklus II mengalami peningkatan dari siklus I 62,6\% meningkat pada siklus II menjadi $88 \%$ yaitu 
meningkat 0,25 sama dengan $25,4 \%$ meningkat. Pada siklus pertama, pertemuan ketiga rata-ratanya mencapai 31,3 sedangkan pada siklus kedua pertemuan ketiga rata-ratanya mencapai 4.

Berdasarkan hasil data penelitian yang telah peneliti uraikan di atas menunjukkan bahwa dengan kegiatan bermain dengan media barang bekas meningkatkan motorik halus anak. Sunardi, (2007: 114) Motorik halus adalah yang menggunakan otot-otot halus atau sebagian anggota tubuh tertentu (tangan dan jari-jari) dan dipergunakan untuk memanipulasi lingkungan. Sebagaimana diketahui bahwa control tangan dimulai dari bahu yang menghasilkan gerak lengan yang kasar, menjadi gerak siku yang baik dan akhirnya gerakan pergelangan tangan dan jari-jari. Maka anak harus slalu dilatih untuk melakukan pergerakan atau latihan jari jemari dalam kegiatan bermain untuk menstimulasi motoric halus anak sehingga keterampilan motoric anak meningkat.

Sunardi (2007: 114) Motorik halus adalah yang menggunakan otot-otot halus atau sebagian anggota tubuh tertentu (tangan dan jari-jari) dan dipergunakan untuk memanipulasi lingkungan. Sebagaimana diketahui bahwa control tangan dimulai dari bahu yang menghasilkan gerak lengan yang kasar, menjadi gerak siku yang baik dan akhirnya gerakan pergelangan tangan dan jari-jari

Melalui kegiatan bermain dengan media barang bekas, keterampilan motoric halus anak dpat ditingkatkan dengan adanya latihan dan stimulasi disetiap kegiatan yang dilakukan pada saat bermain, sehingga keterampilan motoric halus anak yang awalnya ada pada tingakat yang rendah sekarang dapat meningkat menjadi lebih baik lagi.

Kegiatan bermain dengan media bekas ini dilakukan ketika kegiatan pembelajaran dimulai, peneliti mengkondisikan anak terlebih dahulu sehingga anak duduk dengan tertib dan rapi sebelum dimulai pembelajaran. Kemudian guru mulai menyampaikan kegiatan yang akan dilakukan dan menjelaskan langkahlangkahnya setelah itu peneliti baru mengajak anak untuk langsung mencoba bermain dengan media yang sudah disediakan peneliti.

Berdasarkan hasil observasi yang dilakukan pada kelompok B di PAUD Aulia Kota Bengkulu, dapat diketahu bahwa penyebab rendahnya keterampilan motoric halus anak dikarnanya kurannya stimulasi yang dilakukan oleh guru dan kurangnya dalam media/alat peraga sehingga kegiatan pembelajaran yang hanya cenderung meningkatkan keterampilan akademik saja dan keterampilan motoric anak kurang diperhatikan.

Pada siklus I, ketika dilakukan kegiatan bermain dengan media barang bekas sudah terjadi peningkatan cukup baik tetapi belum maksimal karena masih ada anak yang belum mampu menjimpit dengan sekali mengambil, tidak berhenti-berhenti saat bermain dan memegang belum dengan empat jari, memegang benda belum sampai selesai kegiatan, koordinasi mata dan tangan saat kegiatan tidak ada garis yang terlewati, saat kegiatan masih berhentiberhenti. Hal ini belum sesuai dengan pendapat Santrock (2002: 225) Keterampilan motorik halus pada usia 4 tahun, koordinasi motorik halus anak-anak telah semakin meningkat dan menjadi lebih tepat. Pada usia 5 tahun, koordinasi motorik halus anak-anak semakin meningkat. Tangan, lengan, dan tubuh bergerak bersama dibawah komando yang lebih baik dari mata.

Pada siklus II pertemuan ketiga terlihat bahwa keterampilan motorik halus anak berkembang baik dan optimal. Diketahui sepuluh orang anak keterampilan motorik halusnya pada kriteria baik, hal ini karena anak telah memenuhi tiga kriteria dari masing-masing aspek motorik halus 
pada anak saat melakukan kegiatan bermain dengan media barang bekas diantaranya: pada aspek menjimpit yang telah berkembang pada kriteria baik yaitu menggunakan ibu jari dan telunjuk, memegang dengan dua jari tidak jatuh, memegang benda dengan sekali mengambil, tidak berhenti-berhenti saat bermain. Aspek memegang yang telah berkembang pada kriteria baik yaitu memegang benda dengan telapak tangan, memegang benda tidak jatuh, memegang dengan empat jari, memegang benda sampai selesai kegiatan.

Peningkatan keterampilan pada aspek menjimpit, memegang, koordinasi mata dan tangan dalam kegiatan menjahit yang dapat meningkatkan keterampilan motorik halus anak yang sesuai dengan pendapat Yamin (2010:134) keterampilan motorik halus yaitu : a) Menjimpit adalah Perkembangan motorik halus yang semakin baik akan menolong anak untuk dapat memegang tidak dengan telapak tangan, tetapi menggunakan jari-jarinya. b) Memegang adalah anak memegang benda dengan seluruh bagian telapak tangan, sementara jari-jari dikepalkan, la meraih dengan gerakan seperti menggaruk. c) Koordinasi mata dan tangan adalah berkaitan dengan kemampuan memilih suatu objek dan mengkoordinasikannya. Setiap gerakan yang dilakukan anak akan melibatkan koordinasi mata dan tangan juga gerakan motorik kasar dan halus. Semakin banyak gerakan yang dilakukan anak, maka semakin banyak koordinasi yang diperlukan.

Pada kegiatan bermain ini, tiga aspek yang mencakup menjimpit, memegang, koordinasi mata dan tangan sudah baik dan meningkat sesuai dengan tujuan keterampilan motorik halus pendapat Sujiono (2009: 14) tujuan dari keterampilan motorik halus adalah dapat menunjukkan kemampuan anak dalam menggerakan jari jemari terutama terjadinya koordinasi mata dan tangan untuk membuat anak bisa berkreasi seperti menggunting, menggambar, mewarnai, menganyam, dan menjahit.

Berdasarkan hasil pengamatan siklus I dan siklus II diketahui bahwa melalui kegiatan bermain dengan media barang bekas dapat meningkatkan motorik halus anak. Media Barang bekas sangat berkaitan dengan media pembelajaran yaitu media taktil, hal ini sesuai dengan pendapat Fadillah (2012: 211-212) media taktil adalah segala benda yang penggunaannya berkaitan dengan indera peraba yaitu tangan dan kaki, media taktil mengakomodasi gerak motorik halus anak menggunakan keterampilan motorik halus untuk membuat atau mengendalikan bahan pelajaran yang baru sedang dipelajari atau pekerjaan yang sulit.

Diketahui bahwa melalui kegiatan bermain dengan media barang bekas dapat meningkatkan keterampilan motorik halus anak dan memberi manfaat yang sangat baik. Hal ini sesuai dengan pendapat Prasetyono (2008: 138) mengemukakan bahwa manfaat kegiatan menjahit adalah kegiatan yang sangat baik untuk meningkatkan keterampilan jari tangan dan koordinasi tangan-mata, serta melatih anak untuk merencanakan terlebih dahulu apa yang harus dilakukan berikutnya dan juga dapat meningkatkan daya tahan anak untuk tetap berkonsentrasi pada waktu yang relative lama. Dilihat dari setiap hasil perolehan nilai rata-rata dan hasil perolehan ketuntasan klasikal anak pada setiap pertemuan siklus I, siklus II bahwa terdapat suatu peningkatan yang baik untuk anak dalam kemampuan proses kegiatannya.

Berdasarkan uraian pembahasan, dapat disimpulkan bahwa melalui kegiatan bermain dengan media barang bekas dapat meningkatkan keterampilan motorik halus anak. Kegiatan bermain tersebut memerlukan aspek menjimpit, memegang, 
koordinasi mata dan tangan agar dapat meningkatkan keterampilan motorik halus anak.

\section{Keterbatasan Penelitian}

Penelitian ini terbatas pada meningkatkan keterampilan motorik halus anak melalui kegiatan bermain dengan media barang bekas. Adapun aspek memegang, menjimpit, dan koordinasi mata dan tangan dalam melakukan kegiatan kolase. Dalam 3 aspek memegang, menjimpit, dan koordinasi mata dan tangan anak lebih bisa dalam memegang dan menjimpit disebabakan dalam memegang dan menjimpit kancing baju sudah tidak banyak yang jatuh saat melakukan kegiatan bermain dengan media barang bekas.

\section{KESIMPULAN}

\section{Kesimpulan}

Berdasarkan hasil penelitian yang telah dilakukan pada anak kelompok B PAUD Aulia Kota Bengkulu dapat disimpulkan bahwa Melalui kegiatan bermain menggunakan media barang bekas dapat meningkatkan keterampilan motorik halus anak yang meliputi aspek menjimpit, memegang, dan koordinasi mata dan tangan, yang dapat meningkatkan aspek keterampilan motorik halus anak dengan baik. Hal ini dapat dilihat dari pengamatan pada lembar penilaian setiap langkahlangkah kegiatan sebagai berikut : 1) membuat pesawat kardus, 2) membuat kupu-kupu, 3) membuat lebah, 4) membuat kura-kura, 5) mengecat botol, 6) membut ikan.

Melalui kegiatan bermain dengan media barang bekas dapat meningkatkan aspek tererampilan motoric halus anak yaitu menjimpit, memegang, dan koordinasi mata dan tangan secara signifikat. Sedangkan rata-rata keterampilan motorik halus anak pada siklus I sebesar 3,1 (cukup) dan siklus II 4,4 (baik) hal ini dapat dikatakan meningkat pada setiap siklusnya.

\section{Saran}

Saran yang diberikan pada penelitian ini untuk beberapa pihak setelah merefleksi hasil dari pelaksanaan penelitian tindakan kelas (PTK) ini, yaitu, Bagi peneliti Sebaiknya bagi peneliti lebih bagus jika media yang digunakan dalam barang bekas lebih di tambah lagi jika melakukan kegiatan sehingga dapat menambah wawasan bagi anak dalam pengetahuan barang apa saja yang bermanfaat bagi mereka yang ada dilingkungan.

Bagi guru/pendidik, Berdasarkan hasil penelitian diperoleh bahwa melalui kegiatan bermain dengan media barang bekas dapat memberikan dampak positif terhadap perkembangan motorik halus anak. Dengan demikian melalui kegiatan bermain ini diharapkan dapat diterapkan oleh guru dalam mengembangkan potensi yang dimiliki oleh anak usia dini terutama dalam keterampilan motorik halus anak.

\section{DAFTAR PUSTAKA}

Arikunto,Suharsimi. 2010. Penelitian Tindakan Kelas. Jakarta: Bumi Aksara

Decaprio, Richard; 2013; Aplikasi Pembelajaran Motorik Di Sekolah; Jakarta : DIVA Press

Departemenpendidikan Nasional; 2003; Undang-Undang Republik Indonesia No 20 Tahun 2003 Tentang Sistem Pendidikan Nasional; Jakarta :Depdiknas

Kamus-International.com. di akses 23 Januari 2017. http://kamusinternasional.com/definitions/?indone sian_word=hula_hoop

Permendikbud No 146. 2014. Tentang Kurikulum 2013 Pendidikan Anak Usia Dini.Kementrian Pendidikan dan kebudayaan Republik Indonesia 
Permendikbud No 137. 2014. Standar Nasional Pendidikan Anak Usia Dini. Kementrian Pendidikan dan kebudayaan Republik Indonesia

Risnawati. 2008. Strategi Pembelajaran Matematika. Pekanbaru: Suska Press

Santrock, Jhon W. 2011. Masa Perkembangan Anak Edisi 11. Jakarta: SalembaHumanika

Sunardi, sunaryo.2008. Intervensi Dini Anak berkebutuhan Khusus.Jakarta: Depdiknas

Sujiono, Bambang, dkk; 2014; Metodel Pengembangan Fisik; Tanggerang selatan :Universitas Terbuka

YulianiNurani. 2012. Konsep Dasar Pendidikan AnaknUsia Dini. Jakarta: PT. Indeks

YulianiNuranidanBambangSujiono; 2010; Bermain Kreatif Berbasis Kecerdasan Jamak; Jakarta: PT. Indeks

Sumantri.M.S. (2005). Model Pengembangan Keterampilan Motorik Anak Usia Dini. Jakarta.Direktorat Pembinaan Pendidikan Tenaga Kependidikan dan Ketenagaan Perguruan Tinggi. 